\title{
Generation and Quality Analysis of Greywater at Dhaka City
}

\author{
Shaikha Binte Abedin ${ }^{1}$, Zubayed Bin Rakib ${ }^{2}$ \\ ${ }^{1}$ Department of Civil Engineering, University of Information Technology and Science, Dhaka, Bangladesh \\ ${ }^{2}$ Department of Civil Engineering, Presidency University, Dhaka, Bangladesh
}

cross $^{\text {ref }}$ http://dx.doi.org/10.5755/j01.erem.64.2.3992

(received in April, 2013, accepted in June, 2013)

\begin{abstract}
One of the natural resources available in nature is water; however, it is not readily available for domestic use for millions of people across the globe. An increasing global population coupled with growing urbanization worldwide has led to increased demands on water supply. The rapid growth of water-intensive agriculture in developing countries and inefficient water management practices in the developed world are contributing to a global reduction in future freshwater supplies. The world is currently in the midst of cross roads where the unsustainable and impractical uses of water are no longer acceptable. The recycling and reuse of water is therefore imperative in some areas, and increasingly such in the others to meet the demands for urban, industrial and agricultural water requirements. Greywater, which can be defined as all in-building wastewater streams with an exception of toilet wastewater, is a potential water source for urban reuse, as it contains a few or no pathogens and 90 percent less nitrogen than blackwater. This study reveals the generation and quality of greywater in Dhaka City. The groundwater level is depleting by $2 / 3$ of a meter per year in Dhaka. Thus, the recycling and reuse of water have become imperative to meet the demand for it. To analyze the generation of greywater in Dhaka City, water use in five households has been studied and about $67 \%$ of water was found to be reusable, whereas about $17 \%$ of potable water was wasted in toilet flushing. From the quality analysis, kitchen water was found to be polluted to some degree, and judging by its quality, it should not be reused. Greywater must be treated before any kind of reuse as it exceeds the standards of the acceptable quality of potable water and irrigation water.
\end{abstract}

Keywords: Bangladesh, greywater; darkwater; quality, quantity.

\section{Introduction}

Potable water is not abundant in nature. The amount of water available for use on the planet is finite (Athens and Ferguson 1996), and out of the available water, only 3 percent is potable, 2 percent of which is frozen in glaciers and polar ice caps, which leaves only 1 percent as useable water (NASA 2007). The source of potable water is surface water and ground water- out of which surface water is often found polluted. Thus, groundwater plays a very significant role in the supply of water for human activities. In most parts of the developing world, rapid expansion of groundwater exploitation occurred between 1970 and 1990 (UNWWAP 2003). In most countries human populations are growing while water availability is not. As a part of developing world, Dhaka, the capital of Bangladesh, has experienced large scale abstraction of groundwater to meet up the water supply needs with its rapid growing population (Khan and Siddique 2000). Dhaka, historically reported as the city of migrants (Islam 1996) and an over growing population zone, had a population of 4.9 million in 1985 (UNEP 1992), 7.8 million by 1195 (UNDP 1995), which grew to 10 million by 2001 (Akhter et al. 2009) and over 16 million by 2012 (CIA World Factbook 2013). It is the 9th largest city of the world. With this increased population water demand is also increasing. In June 2009, water demand was estimated to be $2470 \mathrm{MLD}$, where the supply was 1930 MLD (Akhter et al. 2009). Supply from surface water and ground water is 292.5 MLD (13\%) and 1679 MLD (84\%), respectively. Water demand in 2030 is estimated to be 4990 MLD (Source: DWASA and IWM).

Ground water depletion has become alarming in Dhaka City for last few years. Data suggested that in 1990 the depth to the water table in the peri-urban areas was about 4 meters, and in the central region it was about 15 meters. However, in 2002 the water 
level in the city center (Motijheel area) was about 50 meters below the mean sea level (DWASA). WASA (Water Supply \& Sewerage Authority) personnel also reported that the city's groundwater level was on average dropping about by $2 / 3$ of a meter per year. At this time water level in the city center is more than 60 meters below the mean sea level (Tamanna 2005). No further extraction from the upper aquifer is viable.

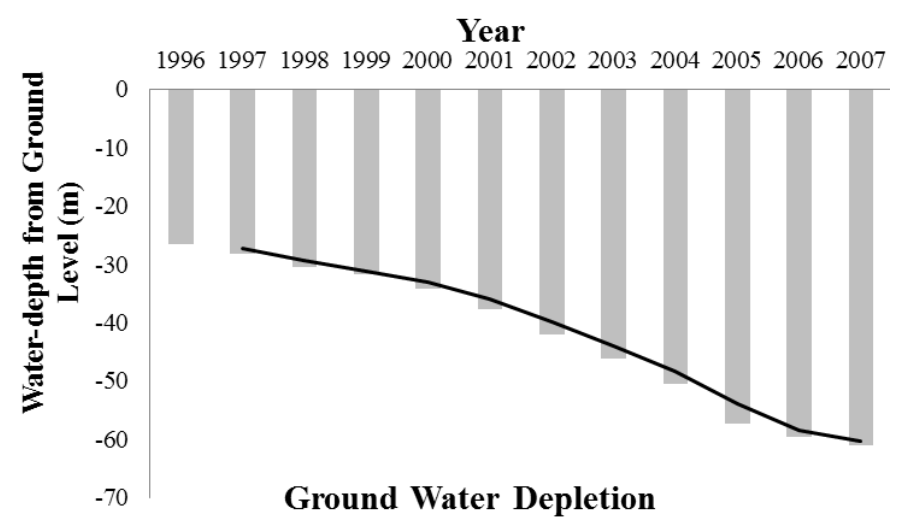

Fig. 1. Ground water depletion of Dhaka City (Source: Tamanna 2005)

Now WASA is installing deep aquifer pumps to abstract water from the second layer. Even this is becoming difficult in many areas. It is high time that we realized the value of fresh water availability in our city. The recycling and reuse of water is therefore imperative in some areas, and increasingly such in the others to meet the demands for urban, industrial and agricultural water requirements. The practice of water reuse involves both reclaiming water sources that would be otherwise released into the environment and using them for a defined purpose (Tchobanoglous and Angelakis 1996, Clark 1977, Dean and Lund 1981). Common applications for reused water include: toilet flushing, irrigation, and vehicle washing (USEPA 2004).

Reuse of wastewater can be an added source to existing water sources, particularly, in arid/semi-arid climatic regions. Most large-scale reuse systems are found in Israel, South Africa, and arid areas of the USA, where alternative sources of water are limited. Even in regions where rainfall is sufficient, because of its spatial and temporal variability, water scarcities are created. For example, Florida, the USA, is not a dry area, but has limited options for water storage, and suffers from water shortages during dry spells. For this reason, wastewater reuse schemes form a vital supplement to the water resource of this region (Vigneswaran and Sundaravadivel 2004).

Greywater is the wastewater or washwater from bathtubs, showers, sinks, washing machines, and dishwashers, which contains few or no pathogens and 90 percent less nitrogen than blackwater (toilet water) (Christensen 2006, CDPH 2001). International Plumbing Code (IPC) defines greywater in its Appendix C, titled "Greywater recycling systems" as "waste discharged from lavatories, bathtubs, showers, clothes washers, and laundry sinks" (Kaduvinal et al. 2007). According to the MCA 75-5-325, "greywater" refers to the "wastewater that is collected separately from a sewage flow and that does not contain industrial chemicals, hazardous wastes, or wastewater from toilets" (Pedersen et al. 2007).
Greywater from low income homes in peri-urban areas is, generally, not contaminated with heavy metals and toxic chemicals found in urban wastewater. Good house practices, such as using small screens to capture food in kitchen basins, exclusion of oils and fats from dishes before washing, can lead to substantial reduction of organic pollution of the greywater and simplify the application of low cost treatment with good treatment results (Angelakis et al. 1995). For instance, houses in rural areas of the MENA region are usually simple and this makes it possible to separate greywater from blackwater with nominal adjustment of sewer pipes inside the house. Greywater separated from the house is collected at a point located in a place that is in the direction of dominant wind so that odor from the treatment unit is blown away from the house (Morel and Diener 2006).

A comprehensive analysis of greywater characteristics was published by Ridderstolpe (2004) for Swedish conditions and by Gulyas (2007) for German conditions. Greywater characteristics in South Africa and Kenya have been analyzed by Carden et al. (2007), Mungai (2008), Kraft (2009), and Raude et al. (2009). Greywater treatment and reuse, for example, as part of ecological sanitation concepts, is a relatively new concept which is often considered as a more simple form of wastewater treatment, but there is still a dearth of experience. Most greywater treatment technologies are consequential from conventional wastewater treatment and were not developed specifically for greywater treatment (Hoffmann et al. 2011). The quantity of greywater generated depends on the income level of the household. As a general rule: the richer the people, the more greywater they produce. Households without in-house water connection produce greywater which is more concentrated than wastewater from wealthy areas, due to the lower water consumption and existing reuse practices (Hoffmann et al. 2011).

For households with dry toilets such as pit latrines, urine diversion dehydration toilets or composting toilets, the greywater production equals 
the total wastewater production of the household. On the other hand, for households with flush toilets, the greywater production is equal to the total wastewater flow minus the amount used for toilet flushing. Greywater constitutes approximately $50 \%$ of the total volume of wastewater discharged for a household (Roesner et al. 2006). Almeida et al. (1999) reported that, $69 \%$ of in-building wastewater is discharged as greywater and $31 \%$ as blackwater. The reuse of greywater holds a number of advantages. Firstly, it is continually and consistently produced onsite, meaning a readily available and reliable source of water is available for reuse. Secondly, greywater is produced in sufficient quantities for reuse applications (Vigneswaran and Sundaravadivel 2004). The reusing greywater has been shown to increase the efficient use of water in the home and minimizes the reliance on municipal water, conserving potable water (Christova-Boal et al. 1995). Greywater use in an average household can lead to an estimated 18-29\% in water savings, according to Christova-Boal et al. (1995).
Unlike many ecological stopgap measures, greywater use is part of the fundamental solution to many ecological problems. It will probably remain an essentially unchanged feature of ecological houses in the distant future. The use of greywater, as a replacement of freshwater for particular uses, can save money and increase effective water supply, especially in regions where irrigation is needed (Asano et al. 1996). For sites with slow soil percolation or other problems, a greywater system can partially or completely substitute a costly, over-engineered septic system (Art Ludwig). Health risks are often cited by regulators as reasons for requiring high-tech expensive systems although there are no recorded instances of greywater-transmitted illness in the US (Art Ludwig). However, greywater may contain infectious organisms. A poorly designed system could become a pathway for infecting people and, thus; should be kept in mind when designing and using the system (Vigneswaran and Sundaravadivel 2004; Winward 2007).

Table 1. Water reclamation in the Middle East

\begin{tabular}{||c|c|c|c|c|c|c|c||}
\hline Country & Bahrain & Cyprus & Jordan & Kuwait & Qatar & Israel & UAE \\
\hline Year & $\mathbf{1 9 9 1}$ & $\mathbf{1 9 9 3}$ & $\mathbf{1 9 9 3}$ & $\mathbf{1 9 9 4}$ & $\mathbf{1 9 9 4}$ & $\mathbf{1 9 9 5}$ & $\mathbf{1 9 9 5}$ \\
\hline $\begin{array}{c}\text { Annual Water Withdrawal } \\
\left(\mathrm{Mm}^{3}\right)\end{array}$ & 239 & 211 & 984 & 538 & 285 & 2000 & 2108 \\
\hline Annual Water Used $\left(\mathrm{Mm}^{3}\right)$ & 15 & 23 & 58 & 80 & 25 & 200 & 185 \\
\hline $\begin{array}{c}\text { Reclaimed water as percentage } \\
\text { of total }\end{array}$ & 6 & 11 & 6 & 15 & 9 & 10 & 9 \\
\hline
\end{tabular}

(Source: Kaduvinal et al. 2007)

In the developed global community, countries involved in active research and use of greywater reuse systems include Japan, the USA, Germany, Canada, the UK, Sweden and Australia (Kaduvinal et al. 2007). Table 1 shows a list of countries where water is reclaimed and its percentage of total water used. In developed countries, the focus is placed on the treatment of greywater with ecotechnological methods (Gunther 2000). Some of the efficient wastewater and greywater systems followed in developed countries like Sweden, Japan, Greece, Germany, and the UK are exemplary and can be emulated elsewhere in the world (Kaduvinal et al. 2007).

Tokyo is one of the cities which have promoted the reuse of wastewater and greywater more than any other cities in the world. In one of the most technologically advanced countries in the world, wastewater treatment plants in Tokyo, Japan, generated $10.8 \times 10^{12}$ liters of water in 1996 (Maeda et al. 1996). The treated waste water is used for toilet flushing, train washing, dilution water for night soil (human feces), landscape irrigation and snow melting (Maeda et al. 1996, Mori 1993). For instance, around $10 \%$ of wastewater treatment plants provide effluent for reuse, and some $8.5 \times 10^{7} \mathrm{~m}^{3}$ effluents are reused each year following the advanced treatment (Maeda et al. 1996).

In Kalmar, Sweden, the greywater purification plant is designed to boost the subsurface flow of water and biological interactions of 15 plants and microorganisms in a triplicate riparian ecotone. The water from the building in Kalmar, which is solely greywater, is treated in the "Wetpark" and reused in the building after purification (Gunther 1995). The construction cost for the above mentioned greywater purification system is about $\$ 700$ per person which also includes the cost of buffer tanks and pumps. The calculations show that the residual nutrient content of the water would be about $0.06 \mathrm{mg}$ nitrogen per liter and $0.02 \mathrm{mg}$ phosphorus per liter, which is less than $1 / 10$ of drinking water standards. After one year of use in Sweden, tests have given the results of 0.007 $\mathrm{mg}$ nitrogen per liter which is highly efficient (Gunther 1999).

Though the Australian authorities discouraged greywater recycling in the early 1990s, the prevailing drought conditions have prompted them to reconsider greywater reuse for non-potable use. A simple valve for diversion of laundry water for landscape irrigation was developed and received interim approval from the authorities (Anderson 1996).

Even though Germany does not face severe water problems, the water conservation measures practiced in Berlin and other parts of Germany are commendable (Nolde 2005). Greywater reuse has been practiced with greater interest and variable success (Nolde 2005).

Like many countries of the Middle East and North Africa, Yemen is facing severe water poverty. The main water source, groundwater from wells, 
suffers from large and uncontrolled extraction and increasing pollution from residential and agricultural use. In addition, mosques are heavy users of potable water as their patrons perform a cleansing ritual before prayer. The water used for this ablution is considered "greywater" and enters the sewage system, which further strains the already scarce water supply. This greywater from mosques is now being reused for irrigation (Global DM 2005).

According to the EPA 2004; the States of Arizona, California, Florida, Hawaii, Massachusetts, New Jersey, North Carolina, Texas, Utah, and Washington in the USA use reclaimed water for toilet flushing fire protection, construction purposes, landscape or aesthetic impoundments and cleaning streets.

Many organizations in Jordan, Palestine, Lebanon and Yemen are now aware of the potential of greywater use in pen urban areas as a practice centered on the women's role in managing the home garden and improving food security for poor families, and as a means for water demand management, and reduction of pollution from septic tank systems. (CSBE 2003, Haddadin 2006) Reclaimed water is mainly used in agriculture and its proportion in comparison to ground and surface water will be on the rise, as the volume of municipal water flow increases and the respective collection and treatment systems expand and enhance. Almost all of Jordan's wastewater is reused either in aquifer recharge or directly in agriculture. (CSBE 2003, Faruqui and AlJayyousi 2002, Mc-llwaine 2004)

Treated wastewater reuse in Jordan, a water strained country, has been practiced as part of public water policy. Government organizations cater for such reuse. Irrigation projects were implemented in the Jordan Valley using treated wastewater blended with storm water impounded by the King Talal Dam. While treated wastewater reuse has been formalized, no attempts have been made to regulate through legislation the reuse of greywater at the household level (Faruqui and Al-Jayyousi 2002, Mc-llwaine 2004, Haddadin 2006, UNDP 2006).

Agricultural irrigation has by far been the largest reported reuse of wastewater. About 41 percent of recycled water in Japan, $60 \%$ in California, the USA, and $15 \%$ in Tunisia are used for this purpose. In developing countries, its application on land has always been the predominant means of disposing municipal wastewater as well as meeting irrigation needs. In China, for example, at least 1.33 million hectares of agricultural land are irrigated with untreated or partially treated wastewater from cities. In Mexico City, Mexico, more than 70000 hectares of cropland outside the city are irrigated with reclaimed wastewater (Vigneswaran and Sundaravadivel 2004).

In this study, the generation and quality analysis of greywater at Dhaka City has been investigated. Greywater samples from five different areas of Dhaka City were collected, and later those samples were tested for water quality parameters. Following the brief explanation of the methodology used, the results section consists of descriptions of the quantity of greywater generated from different areas on working days and holidays, and the quality analysis of greywater from the Azimpur area. The main objective of this study is to quantify the amount of greywater generated in Dhaka City and provide an overview of its quality; and reveal the potentials of recycling and reuse of greywater to meet the demand for urban, industrial and agricultural water requirements.

\section{Methodology}

In order to estimate the water consumption of households, five houses in five areas were selected, where suitable environment could be received to complete the task. The areas selected were Azimpur, Uttara, Rampura, Monipuripara, and Goran (Figure 2). The determination of water use is done for two categories of days- working days and holidays. Data were taken for several days and then average values are used for detailed analysis. Information was obtained of water used for cloth washing, dish washing, floor washing, hand washing, bathing, ablution, drinking water and toilet flushing. Data was collected by a questionnaire survey among the members of the household. All the houses were surveyed over a week. Though washing procedures differed among the houses, for that specific week they were requested to use a specific procedure for the purpose of data collection. To determine the water used, apart from toilet flushing, a specific bucket was used for holding water. After washing, the person was asked for the number of buckets of water used for washing, and then multiplying this number with the size (waster holding capacity) of bucket the amount of water used was determined. To determine the water used for toilet flushing, the members were requested to keep the count of number of times they flushed the flush tank, and by multiplying the size (waster holding capacity) of the flush tank the amount of darkwater generated was determined.

For qualitative analysis, greywater was collected from Azimpur only. Five categories of water were tested which include water used for cloth washing, dish washing, floor washing, hand washing and bathing. Samples were taken 3 times and tested in the "Environmental Engineering Laboratory" of Bangladesh University of Engineering and Technology (BUET) for eight water quality parameters which are-pH, Color, Turbidity, Total Dissolved Solids (TDS), Total Suspended Solids (TSS), Chemical Oxygen Demand (COD), Biochemical Oxygen Demand (BOD)and Faecal Coliform (FC).

$\mathrm{pH}$ is a measure of the acidity or basicity of an aqueous solution. Pure water is said to be neutral, with a $\mathrm{pH}$ close to 7.0 at $25^{\circ} \mathrm{C}\left(77^{\circ} \mathrm{F}\right)$. Ideally, water has no color though ordinarily we think of water as being blue in color. Infinitely small microscopic particles add color to water. Colloidal suspensions and non-colloidal organic acids as well as neutral salts also affect the color of water. Pt-Co is an arbitrary standard scale that has been developed for measuring 
color intensity in water samples. When water is rated as having a color of 5 units, it means: the color of this water is equal in intensity to the color of distilled water containing 5 milligrams of platinum as potassium chloroplatinate per liter. Turbidity is the lack of clarity in water. The term 'turbid' is applied to water containing suspended matter that interferes with the passage of light through the water. Turbidity may be caused by a wide variety of suspended substances of various sizes ranging in size from colloidal to coarse particles. Turbidity is measured in Nephelometric Turbidity Units (NTU). The chemical oxygen demand (COD) and biochemical oxygen demand (BOD) tests are commonly used to indirectly measure the amount of organic compounds in water. COD values are greater than BOD values especially when biologically resistant organic matter is present. Total Solids is the sum of Total Dissolved Solids (TDS) and Total Suspended Solids (TSS) is water. Faecal Coliform (FC) is determined by counting the number of coliform colonies formed with the aid of $\mathrm{M}-\mathrm{FC}$ agar and the incubator and is expressed in CFU/100 ml. In pure drinking water, there should not be any presence of FC. Table 2 summarizes the methods and equipment used for determination of those water quality parameters.

Although greywater has much lower oxygen demand than blackwater as it contains $90 \%$ less nitrogen than blackwater, but still it should be treated before any kind of reuse. Precautions must be taken in order to avoid accidental connections between freshwater and greywater plumbing. Untreated greywater should not be applied onto lawns, or fruit and vegetables that are eaten raw. Although greywater has much lower oxygen demand than blackwater as it contains $90 \%$ less nitrogen than blackwater, but still it should be treated before any kind of reuse. Precautions must be taken in order to avoid accidental connections between freshwater and greywater plumbing. Untreated greywater should not be applied onto lawns, or fruit and vegetables that are eaten raw. Greywater should be used within 24 hours before bacteria multiply. The following are the requirements of greywater parameters that must be met in the agricultural sector.

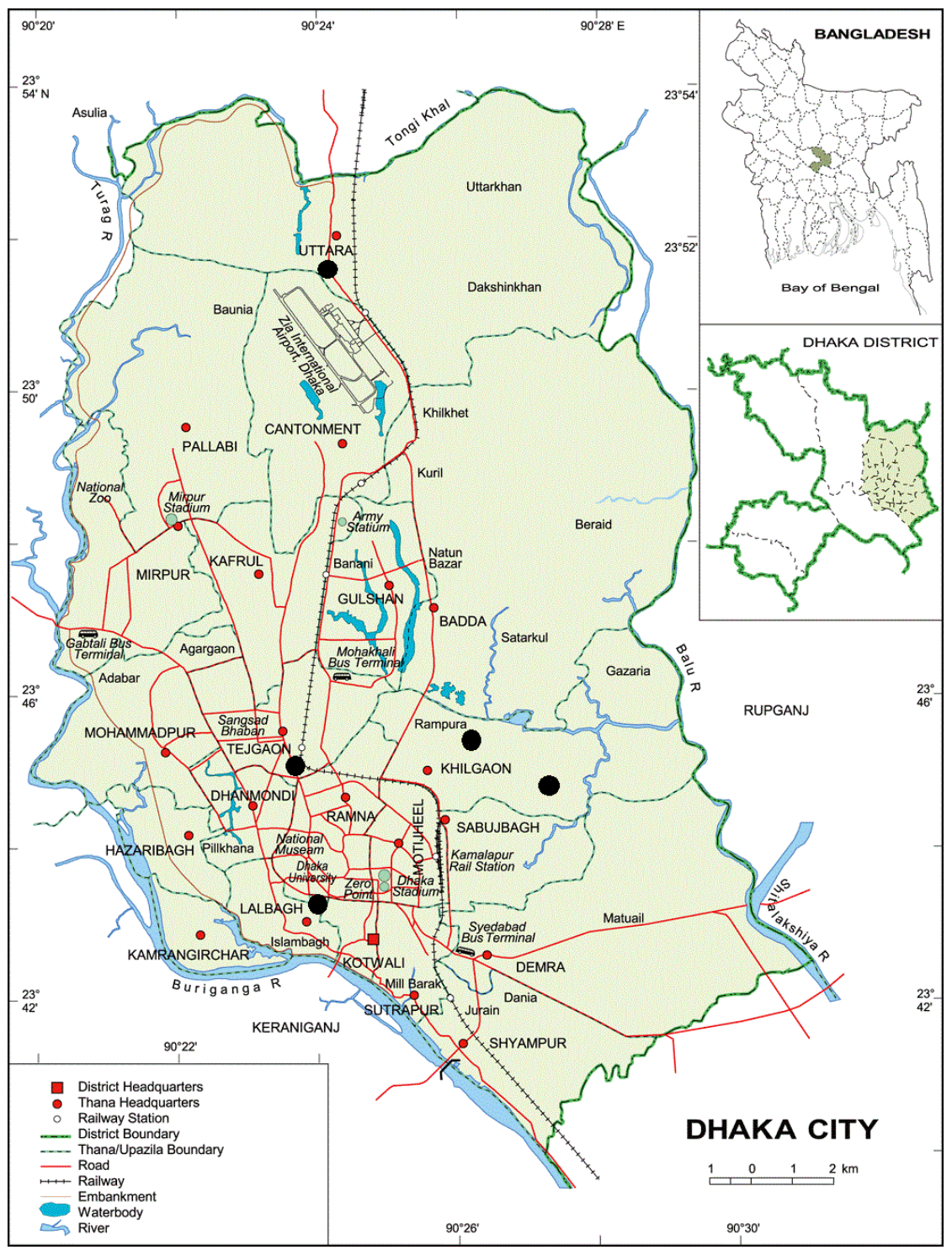

Fig. 2. Map showing selected areas (circled) of Dhaka City for determination of water use 
Table 2. Parameters tested

\begin{tabular}{||c|c|c||}
\hline Parameter & Method & Equipment \\
\hline $\mathrm{pH}$ & USEPA 150.1;SM 4500-H $\mathrm{H}^{+} \mathrm{B}$ & WTW Glass Probes and HACH HQ10 $\mathrm{pH}$ Meter \\
\hline Color & USEPA 110.2;SM 2120 C & DR4000 UV Spectrophotometer \\
\hline Turbidity & USEPA 180.1 Rev 2;SM 2130 B & HACH Portable Turbidimeter \\
\hline TDS & USEPA 160.2;SM 2540 B-D & Oven \\
\hline TSS & USEPA 160.2;SM 2540 D & Wven \\
\hline BOD & USEPA 405.1;SM 5210 B;SM 5210 D & DR4000 UV Spectrophotometer \\
\hline COD & USEPA 410.4;SM 5220 D & Vacuum pump and Incubator \\
\hline FC & SM 9200G &
\end{tabular}

For the purpose of successful implementation of greywater recycling different countries of the world have already started the quantification and characterization of greywater. In most countries guidelines and standards either do not exist or are being revised or expanded. Guideline values of greywater parameters for agricultural sector and potable water are listed in Table 3 and the available criteria for toilet flushing and domestic water recycling are shown in Table 4.

Table 3. Guideline values of greywater parameters for agricultural sector and potable water

\begin{tabular}{|c|c|c|c||}
\hline \multirow{2}{*}{ Parameters } & Agricultural Sector & \multicolumn{2}{|c|}{ Potable Water } \\
\cline { 2 - 4 } & $\begin{array}{c}\text { Maximum Permitted } \\
\text { Values }\end{array}$ & $\begin{array}{c}\text { Bangladesh Standard } \\
\text { (ECR,1997) }\end{array}$ & $\begin{array}{c}\text { WHO Guideline } \\
\text { Values,2004 }\end{array}$ \\
\hline $\mathrm{pH}$ & $6.5-8.5$ & $6.5-8.5$ & $6.5-8.5$ \\
\hline $\mathrm{BOD}_{5}, 20^{\circ} \mathrm{C}(\mathrm{mg} / \mathrm{l})$ & 120 & 0.2 & - \\
\hline $\mathrm{COD}(\mathrm{mg} / \mathrm{l})$ & 200 & 4 & - \\
\hline $\mathrm{TSS}(\mathrm{mg} / \mathrm{l})$ & 120 & 10 & $1000^{\mathrm{b}}$ \\
\hline TDS (mg/l) & 13400 & 1000 & $15^{\mathrm{c}}$ \\
\hline Color (Pt-Co unit) & - & 15 & $5^{\mathrm{c}}$ \\
\hline Turbidity (NTU) & - & 10 & 0 \\
\hline FC (MPN/100ml) & 1000 & 0 & $0^{\mathrm{c}}$ \\
\hline
\end{tabular}

$c=$ consumer acceptability consideration; $b=$ taste threshold/consideration $\quad$ (Source: M.Platzer et al. 2004)

For the purpose of successful implementation of greywater recycling different countries of the world have already started the quantification and characterization of greywater. In most countries guidelines and standards either do not exist or are being revised or expanded. Guideline values of greywater parameters for agricultural sector and potable water are listed in table 3 and the available criteria for toilet flushing and domestic water recycling are available which are shown in table 4.

Table 4. Guidelines and standards for water reuse for toilet flushing and domestic water recycling

\begin{tabular}{|c|c|c|c|c|c|c|c|c||}
\hline \multirow{2}{*}{ Parameter } & \multicolumn{2}{|c|}{ Toilet Flushing } & \multicolumn{6}{|c||}{ Domestic Water Recycling } \\
\cline { 2 - 9 } & US & Japan & WHO & USEPA & $\begin{array}{c}\text { USA, } \\
\text { NSF }\end{array}$ & Australia & UK & Germany \\
\hline $\mathrm{pH}$ & $6.0-9.0$ & $5.8-8.6$ & & $6.0-9.0$ & & & & $6.0-9.0$ \\
\hline BOD $_{5}(\mathrm{mg} / \mathrm{l})$ & $\leq 10$ & & & 10 & & 20 & 20 \\
\hline Turbidity (NTU) & $\leq 2$ & & & 5 & & 2 & $1.0-2.0$ \\
\hline TC (no./100ml) & & & $1000(\mathrm{~m}), 200(\mathrm{~g})$ & $<10$ & & $<1$ & ND & 100 \\
\hline FC (no./100ml) & ND & $\leq 10$ & & $<10$ & $<240$ & $<4$ & & 10 \\
\hline
\end{tabular}

$N D=$ not detectable $;(m)=$ mandatory, $(\mathrm{g})=$ guideline

\section{Results and Discussion}

\subsection{Quantification of Greywater Generation}

From the data in Table 5 it is apparent that, the per capita consumption of water of middle class families in Dhaka City varies from about 200 to 300 liters per day, with an average of approximately 252 liters per capita per day. From the last row of the Table it is quite clear that per capita water consumption differs from area to area. Water is fairly available in Rampura due to the current "Mahanagar"
(Source: Tamanna 2005)

project, for which the water consumption (323 liters per capita per day) is comparably higher for this area than the others. Whereas, in Goran the consumption is the lowest (224 liters per capita per day) as watersupply is not available throughout the day.Uttara, being a more planned part of the city, has a fairly well supply of water, which is comprehensible from the water use data. From Table 5 it is also understandable that water consumption on weekdays is less than water consumption on holidays, owing to the fact that people spend more time at home in holidays than on weekdays. 
Table 5. Water consumption

\begin{tabular}{|c|c|c|c|c|c|c|c|c|c|c|c||}
\hline \multirow{2}{*}{ Area } & \multicolumn{3}{|c|}{ Water consumption on Holidays (Liter/day) } & \multicolumn{3}{c|}{ Water consumption on Weekdays (Liter/day) } \\
\cline { 2 - 14 } & Rampura & Uttara & Azimpur & Monipuripara & Goran & Rampura & Uttara & Azimpur & Monipuripara & Goran \\
\hline Family Member & 4 & 4 & 3 & 4 & 5 & 4 & 4 & 3 & 4 & 5 \\
\hline Bathing & 350 & 250 & 220 & 250 & 300 & 325 & 200 & 200 & 250 & 280 \\
\hline Cloth washing & 250 & 250 & 150 & 210 & 200 & 240 & 250 & 150 & 210 & 180 \\
\hline Drinking Water & 8 & 7.5 & 9 & 7.5 & 9 & 7 & 6 & 7.5 & 6 & 8 \\
\hline Dish washing & 300 & 200 & 90 & 140 & 180 & 200 & 150 & 70 & 100 & 150 \\
\hline Hand washing & 65 & 70 & 40 & 30 & 30 & 40 & 50 & 40 & 30 & 30 \\
\hline Ablution & 120 & 80 & 30 & 40 & 70 & 80 & 50 & 30 & 30 & 45 \\
\hline Floor washing & 50 & 200 & 50 & 90 & 80 & 50 & 200 & 50 & 90 & 80 \\
\hline Toilet Flushing & 150 & 150 & 170 & 210 & 250 & 90 & 120 & 150 & 190 & 210 \\
\hline Consumption(lpcd) & $\mathbf{3 2 3}$ & $\mathbf{3 0 2}$ & $\mathbf{2 5 3}$ & $\mathbf{2 4 4}$ & $\mathbf{2 2 4}$ & $\mathbf{2 5 8}$ & $\mathbf{2 5 7}$ & $\mathbf{2 3 3}$ & $\mathbf{2 2 7}$ & $\mathbf{1 9 7}$ \\
\hline
\end{tabular}

lpcd: liter per capita per day

Table 6. Average water consumption (in percentage)

\begin{tabular}{||c|c|c|c||}
\hline Type of Water & $\begin{array}{c}\text { Average Holiday Water } \\
\text { consumption (\%) }\end{array}$ & $\begin{array}{c}\text { Average Weekday Water } \\
\text { consumption (\%) }\end{array}$ & $\begin{array}{c}\text { Average Water } \\
\text { consumption (\%) }\end{array}$ \\
\hline Bathing & 25.8 & 27.1 & 26.5 \\
\hline Cloth washing & 19.8 & 22.1 & 21.0 \\
\hline Drinking Water & 0.8 & 0.8 & 0.8 \\
\hline Dishwashing & 16.4 & 14.1 & 4.3 \\
\hline Hand washing & 4.4 & 4.2 & 5.5 \\
\hline Ablution & 6.0 & 5.0 & 9.3 \\
\hline Floor washing & 8.7 & 9.9 & 17.5 \\
\hline Flush & 18.0 & 16.9 & \\
\hline \multicolumn{2}{|l|}{ Generation of greywater (considering kitchen water as greywater): 82.50 \% } \\
\hline \multicolumn{2}{|l}{ Generation of greywater (considering kitchen water as darkwater): 67.30 \% } \\
\hline
\end{tabular}

Table 7. Average water consumption for different areas (from DWASA-Water bill)

\begin{tabular}{||c|c|c|c|c|c||}
\hline \multicolumn{2}{|c|}{ Uttara area, 2011 } & \multicolumn{2}{c|}{ Monipuripara area, 2011 } & \multicolumn{2}{c||}{ Goran area, 2011 } \\
\hline $\begin{array}{c}\text { Total people living in the } \\
\text { building = 62 }\end{array}$ & \multicolumn{2}{c|}{$\begin{array}{c}\text { Total people living in the } \\
\text { building }=183\end{array}$} & \multicolumn{2}{c||}{$\begin{array}{c}\text { No of people living in the building }= \\
\text { 20 }\end{array}$} \\
\hline Month & $\begin{array}{c}\text { Consumption } \\
\text { (liter) }\end{array}$ & Month & $\begin{array}{c}\text { Consumption } \\
\text { (liter) }\end{array}$ & Month & $\begin{array}{c}\text { Consumption } \\
\text { (liter) }\end{array}$ \\
\hline January & 545000 & January & 1208000 & January & 92000 \\
\hline February & 535000 & February & 1795000 & February & 80000 \\
\hline March & 537000 & March & 1680000 & March & 99000 \\
\hline April & 535000 & April & 1913000 & April & 101000 \\
\hline May & 539000 & May & 2039000 & May & 103000 \\
\hline June & 1425000 & June & 1967000 & June & 150000 \\
\hline July & 698000 & July & 2021000 & July & 212000 \\
\hline August & 782000 & August & 2119000 & August & 208000 \\
\hline September & 658000 & September & 1931000 & September & 186000 \\
\hline October & 705000 & October & 2611000 & October & 175000 \\
\hline November & 678000 & November & 1933000 & November & 102000 \\
\hline December & 675000 & December & 1813000 & December & 72000 \\
\hline Consumption (lpcd) & $\mathbf{3 6 7 . 3 ~ l i t e r ~}$ & Consumption (lpcd) & $\mathbf{3 4 5 ~ l i t e r}$ & Consumption (lpcd) & $\mathbf{2 1 6 . 4 ~ l i t e r ~}$ \\
\hline
\end{tabular}

lpcd: liter per capita per day

Table 6 shows the average water consumption of both holidays and weekdays in a percentage form. The Table indicates that the majority of water use in household is for bathing and cloth washing. Dish washing and toilet flushing account for the next major use of household water. It is important to note that almost $17-18 \%$ of potable water is used for toilet flushing which can be saved by reusing greywater, which could result in saving nearly 45 liters per capita per day of potable water (considering average water use of approximately 250 liters per capita per day). Looking at the Table it can be said that about $82 \%$ (200 liters per capita per day) of potable water (including kitchen water) can be reused as greywater. Excluding kitchen water (as it is exceedingly polluted), about $67 \%$ of the generated water is greywater, that is about 170 liters per capita per day. Roesner et al. (2006) observed 50\% of the total volume of wastewater discharged for a household to be greywater, whereas Almeida et al. (1999) reported 
that, $69 \%$ of in-building wastewater is discharged as greywater, which is very similar to the results $(67 \%)$ of the current study. This huge quantity of water can be diverted from the sewage water system and reused after basic treatments. Greywater quantities of 0.5-1 liter of water per hand washing event, 40 liters water having a 5-minute shower and 5-25 liters water for preparing a three-course meal and dish washing were measured at sustainable sanitation projects in Peru and Brazil by Hoffmann et al. (2011).

Table 7 displays the average water consumption of three of the selected areas in Dhaka City obtained from the monthly water bills of DWASA (Dhaka Water Supply and Sewerage Authority). It is seen from the Table that the amount of water use (liter per capita per day) obtained from the survey does not coincide with the values reported by DWASA. Particularly, there is a huge gap (nearly 30\%) for Monipuripara area. While water use from the survey of Uttara and Monipuripara areas is found to be lower than the value reported by DWASA, the opposite is found for Goran area. This gives an indication that a lot of water is lost due to leakages, misuses, faulty connections and faucets.

\subsection{Analysis of the Quality of Greywater}

Table 8 summarizes test results of the eight water quality parameters, $\mathrm{pH}$, Color, Turbidity, TDS, TSS, COD, BOD 5 and FC of the greywater samples.

From this analysis we can see that $\mathrm{pH}$ of greywater has the range of $6.45 \pm 1.05$, kitchen water being the most acidic. The average $\mathrm{pH}$ value of kitchen water is 5.804, which is fairly acidic due to the presence of organic acids produced by edible organic compounds. Cloth washing water has an average $\mathrm{pH}$ of 7.401 , with a value of 7.469 , and it shows very little deviation from the average. It is slightly basic due to the use of soaps and detergents for cloth washing purposes. Water from floor wash, bath and basin is all slightly acidic (average $\mathrm{pH}$ 6.26.7). $\mathrm{pH}$ value of 6.6-8.7 in a greywater study for Brisbane was reported by Jeppesen (1996) and Christova-Boal et al. (1995) reported $\mathrm{pH}$ value of 6.48.1 and 6.3-9.5 for bath water and cloth wash, respectively, (CSBE 2003) which is in congruence with our test results. The standard $\mathrm{pH}$ range of potable water irrigation water is 6.5-8.5 according to the Bangladesh Standard (ECR 1997) and WHO Guideline Value (2004). Elimination of the kitchen water makes the average value of $\mathrm{pH}$ of greywater to be 6.70; which makes it suitable for reuse.

The true color has been measured by filtering the water sample. The highest color came from kitchen water (516.7Pt-Co), as it contains much more organic matters derived from food. The lowest color was obtained for floor wash, although the value (262 Pt$\mathrm{Co}$ ) is quite high from the standard point of view. The color of floor wash could be due to the presence of dissolved salts. The color of the water from cloth washing is due to the dye of clothes and dissolved salts from detergent. The color of bath water and hand wash could be from soap and dissolved salts. The average value of color of greywater is $395 \mathrm{Pt}-\mathrm{Co}$, having a range of $355 \pm 185 \mathrm{Pt}-\mathrm{Co}$ which is fairly high.

Greywater is high in turbidity as it contains lots of suspended particles resulting from washing activities. The analysis shows that turbidity is the highest for water of cloth washing and the lowest for basin water, the standard value of turbidity according to the Bangladesh Standard (ECR 1997) and the WHO guideline value (2004) being 10NTU and $5 \mathrm{NTU}$, respectively. The range of turbidity of greywater is $241 \pm 177$ NTU. Comparing with these standard values we can see that greywater has high turbidity and should be treated before reuse. Turbidity of the water of floor wash displays a high degree of variation, whereas the other four categories show less deviation. Khong (2009) reported turbidity values of $84.8 \mathrm{mg} / \mathrm{l}$ and $164 \mathrm{mg} / \mathrm{l}$ for bath and hand basin, respectively (Jefferson et al. 2004), which are analogous to the values obtained from our test samples. Suspended solids (dirt, lint), organic material, oil and grease, sodium, nitrates and phosphates (from detergent) have increased salinity, while $\mathrm{pH}$ and bleach are the probable sources of turbidity of greywater from cloth wash (CSBE 2003). Bacteria, hair, organic material and suspended solids (skin, particles, lint), oil and grease, soap and detergent residue usually result in turbidity of greywater obtained from bath water and basin water (CSBE 2003).

Greywater has a high range of COD values (600$2500 \mathrm{mg} / \mathrm{l})$. Kitchen water has the highest average COD value $1846.3 \mathrm{mg} / \mathrm{l}$, whereas basin water has the lowest $(672 \mathrm{mg} / \mathrm{l})$. Water from floor wash and kitchen displays a high degree of variation. Both these categories, particularly, kitchen water, bear a high COD value due to the presence of organic compounds from human uses. Khong (2009) testified COD values of $420 \mathrm{mg} / \mathrm{l}$ and $587 \mathrm{mg} / \mathrm{l}$ for bath and hand basin, respectively (Jefferson et al. 2004), which are slightly lower than the values obtained from our test samples. The Bangladesh standard (ECR 1997) of COD for potable water is $4 \mathrm{mg} / \mathrm{l}$ and that for agricultural use is $200 \mathrm{mg} / \mathrm{l}$. From the data; it can be said that it is not wise to reuse the kitchen water. Greywater from other sources also requires treatment before reuse.

The standard of $\mathrm{BOD}_{5}$ for wastewater discharge to the irrigated land is $100 \mathrm{mg} / \mathrm{l}$ (Bangladesh Environmental Conservation Rules 1997, schedule10). But, as we can see $\mathrm{BOD}_{5}$ of greywater has a much higher value, it needs to be treated before any kind of reuse. Greywater from kitchen water can have a very high organic load from food scraps, oil and grease which can result in a high concentration of organic matter of more than $500 \mathrm{mg}$ BOD/L (Hoffmann et al 2011). Apart from cloth washing water, $\mathrm{BOD}_{5}$ of the rest of greywater is in the range of $300-400 \mathrm{mg} / \mathrm{l}$. The kitchen water has the highest value of $\mathrm{BOD}_{5}$ due to organic matter from food. It is very interesting to note that average COD of cloth washing water is $1253.3 \mathrm{mg} / \mathrm{l}$, but the average $\mathrm{BOD}_{5}$ value is only $73.7 \mathrm{mg} / \mathrm{l}$; which indicates that a lot of biodegradable organic matters are present. Water from floor wash and cloth wash shows a high amount 
of disparity. $\mathrm{BOD}_{5}$ of $90-120 \mathrm{mg} / \mathrm{l}$ was affirmed by Jeppesen (1996) for greywater study in Brisbane and Christova-Boal et al. (1995) reported BOD $_{5}$ of 45-330 $\mathrm{mg} / \mathrm{l}$ and $10-520 \mathrm{mg} / \mathrm{l}$ for bath water and cloth wash, respectively (CSBE 2003). Results of bath water from previous studies are analogous to our test results, but cloth wash has revealed comparatively lower $\mathrm{BOD}_{5}$ values. Khong (2009) quantified BOD values of 146 $\mathrm{mg} / \mathrm{l}$ and $155 \mathrm{mg} / \mathrm{l}$ for bath and basin water, respectively (Jefferson et al. 2004), which are considerably lower than the values obtained from our test samples.

Table 8. Results of test of quality parameters
For TDS, we can see that cloth wash has the highest average value $(1120.3 \mathrm{mg} / \mathrm{l})$ as there are detergents dissolved in it along with dissolved salts. Basin water has a fairly low TDS value. TDS of greywater from floor wash, kitchen and bath falls in the range $450-650 \mathrm{mg} / \mathrm{l}$. The standard of TDS for irrigation water is $1180(\mathrm{mg} / \mathrm{l})$. As it is seen that TDS of all the samples is below this maximum range, greywater can be considered to be suitable enough for agricultural use without any treatment.

\begin{tabular}{|c|c|c|c|c|c|c|}
\hline Parameter & Sample no & Floor Wash & Cloth Wash & Kitchen Water & Bath water & Basin Water \\
\hline \multirow{4}{*}{$\mathrm{pH}$} & 1 & 6.842 & 7.412 & 5.425 & 6.001 & 6.232 \\
\hline & 2 & 6.57 & 7.469 & 5.813 & 6.321 & 6.343 \\
\hline & 3 & 6.726 & 7.321 & 6.175 & 6.531 & 6.823 \\
\hline & Average & 6.713 & 7.401 & 5.804 & 6.284 & 6.466 \\
\hline \multirow{4}{*}{ Color (Pt-Co) } & 1 & 169 & 254 & 540 & 450 & 410 \\
\hline & 2 & 337 & 360 & 520 & 520 & 490 \\
\hline & 3 & 280 & 320 & 490 & 460 & 320 \\
\hline & Average & 262 & 311.3 & 516.7 & 476.7 & 406.7 \\
\hline \multirow{4}{*}{ Turbidity (NTU) } & 1 & 418 & 410 & 303 & 74 & 65 \\
\hline & 2 & 247 & 391 & 345 & 90.5 & 85.2 \\
\hline & 3 & 354 & 386 & 312 & 102 & 95 \\
\hline & Average & 339.7 & 395.7 & 320 & 88.8 & 81.7 \\
\hline \multirow{4}{*}{$\mathrm{COD}(\mathrm{mg} / \mathrm{l})$} & 1 & 579 & 1056 & 1104 & 560 & 654 \\
\hline & 2 & 614 & 1105 & 2510 & 804 & 754 \\
\hline & 3 & 1473 & 1599 & 1925 & 706 & 608 \\
\hline & Average & 888.6 & 1253.3 & 1846.3 & 690 & 672 \\
\hline \multirow{4}{*}{$\mathrm{BOD}_{5}(\mathrm{mg} / \mathrm{l})$} & 1 & 640 & 86 & 600 & 320 & 300 \\
\hline & 2 & 176 & 25 & 600 & 420 & 380 \\
\hline & 3 & 320 & 110 & 560 & 360 & 320 \\
\hline & Average & 378.6 & 73.7 & 586.7 & 366.7 & 333.3 \\
\hline \multirow{4}{*}{ TDS (mg/l) } & 1 & 455 & 832 & 654 & 432 & 155 \\
\hline & 2 & 775 & 1573 & 684 & 532 & 215 \\
\hline & 3 & 661 & 956 & 615 & 445 & 118 \\
\hline & Average & 630.3 & 1120.3 & 651 & 469.7 & 162.7 \\
\hline \multirow{4}{*}{ TSS (mg/l) } & 1 & 448 & 875 & 1235 & 74 & 62 \\
\hline & 2 & 751 & 1574 & 2414 & 83 & 54 \\
\hline & 3 & 820 & 1160 & 1925 & 79 & 59 \\
\hline & Average & 673 & 1203 & 1858 & 78.7 & 58.3 \\
\hline \multirow{4}{*}{$\begin{array}{c}\mathrm{FC}(\mathrm{CFU} / 100 \\
\mathrm{ml})\end{array}$} & 1 & TNTC & 1600 & TNTC & 900 & 400 \\
\hline & 2 & 45000 & 1400 & 287000 & 700 & 500 \\
\hline & 3 & 40000 & 1200 & 165000 & 600 & 400 \\
\hline & Average & 42500 & 1400 & 226000 & 733.3 & 433.3 \\
\hline
\end{tabular}

TNTC= Too Numerous to Count

Total suspended solid, TSS, is higher in kitchen water because wash water from food, vegetables, fish, etc. is added to it. Greywater from kitchen sinks can have a high amount of sand from washing of vegetables. Furthermore, the use of ash for dishwashing can cause a high value of suspended particles (Hoffmann et al 2011). Except the basin water, all types of greywater cross the limit of the NATA standard $67 \mathrm{mg} / \mathrm{l}$. Water from floor wash, cloth wash and kitchen has a very high degree of variation. Bath water and basin water have fairly low amounts of TSS. Christova-Boal et al. (1995) reported $\mathrm{pH}$ value of $43-380 \mathrm{mg} / \mathrm{l}$ and $10-520 \mathrm{mg} / \mathrm{l}$ for bath water and cloth wash, respectively (CSBE 2003). Outcomes from our tests indicate similar values for bath water (74-83 mg/l), but higher average values for cloth wash (875-1574 mg/l).

Kitchen water and floor wash have a high number of Fecal Coliform (FC). While testing with a dilution factor of 100, FC of kitchen water and floor wash were too many to count. A study for greywater in Arizona has revealed FC of 20-7,640,000 CFU/100 $\mathrm{ml}$ (CSBE 2003), which is in congruence with the results of kitchen water and floor wash of our study. The other categories of greywater also have a high number of FC. This concludes that greywater should be treated for FC before reuse.

Figure 3 shows the contrast of the greywater quality parameters; (a), (b) and (c) display the average 
value of parameters of the samples tested and (d) illustrates the $\mathrm{pH}$ of individual samples.

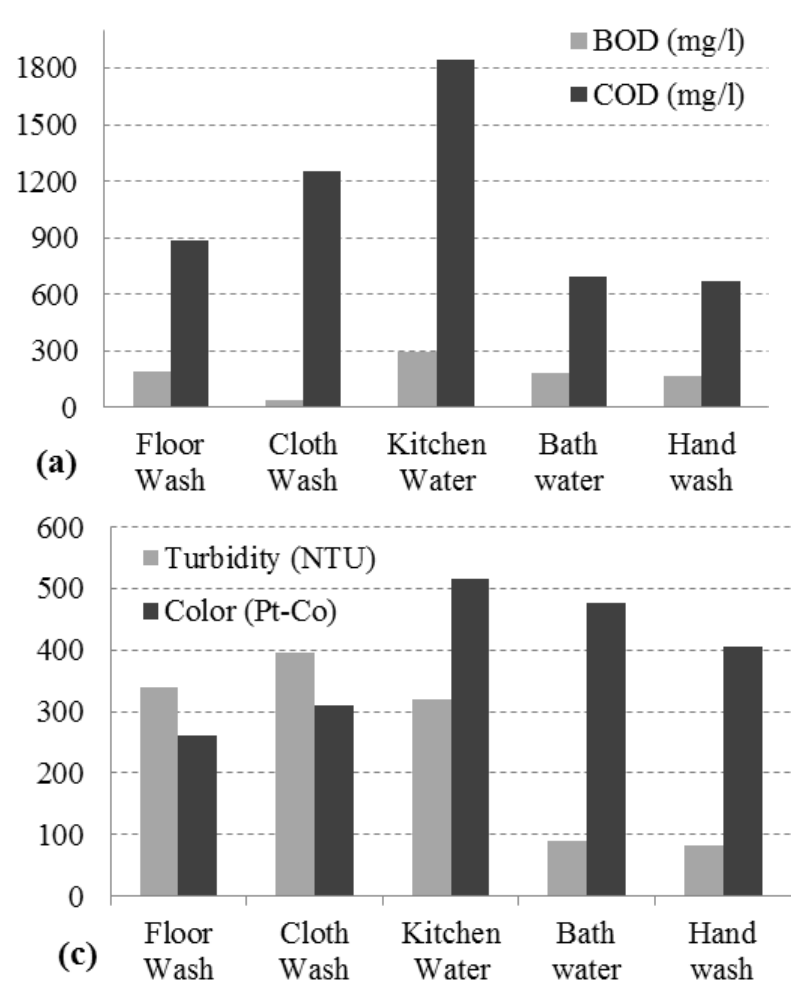

Fig. 3. Comparison of quality parameters of greywater Turbidity-Color (d) $\mathrm{pH}$

\section{Conclusions}

This study has mainly highlighted the generation and quality assessment of greywater from different locations in Dhaka City. The average water consumption for the middle class families is $200-300$ liters per capita per day. The bulk of water in household is used for bathing and cloth washing. Dish washing and toilet flushing account for subsequent major uses of household water. Almost 17-18 \% of potable water is used for toilet flushing which can be saved by reusing greywater. Excluding kitchen water, about $67 \%$ of the generated water is greywater (i.e. about 170 liters per capita per day) which could be reused after treatment. The values of the tested eight parameters (i.e. $\mathrm{pH}$, Color, Turbidity, BOD, COD, TDS, TSS, FC) of the generated greywater exceeded the standard permissible values of water quality. Kitchen water was found to be the most polluted, which indicates its non-reusability. After exclusion of kitchen water, greywater has average $\mathrm{pH}$ 6-7.5, color 170-520 Pt-Co, turbidity 65-420 NTU, TDS 120-1570 $\mathrm{mg} / \mathrm{l}$, TSS 55-1575 mg/l, BOD 12-320 mg/l, COD 580-1600 mg/l, Fecal coliform 400-42500 CFU/100ml, which exceeds the maximum permissible range of standard quality of irrigation water and potable water. Kitchen wastes are high in suspended solids, fats, oils, and grease, and their generally high organic content encourages the growth of bacteria. Also, high fat and solid content cause problems for filtration and pumping. Due to contamination by oils,
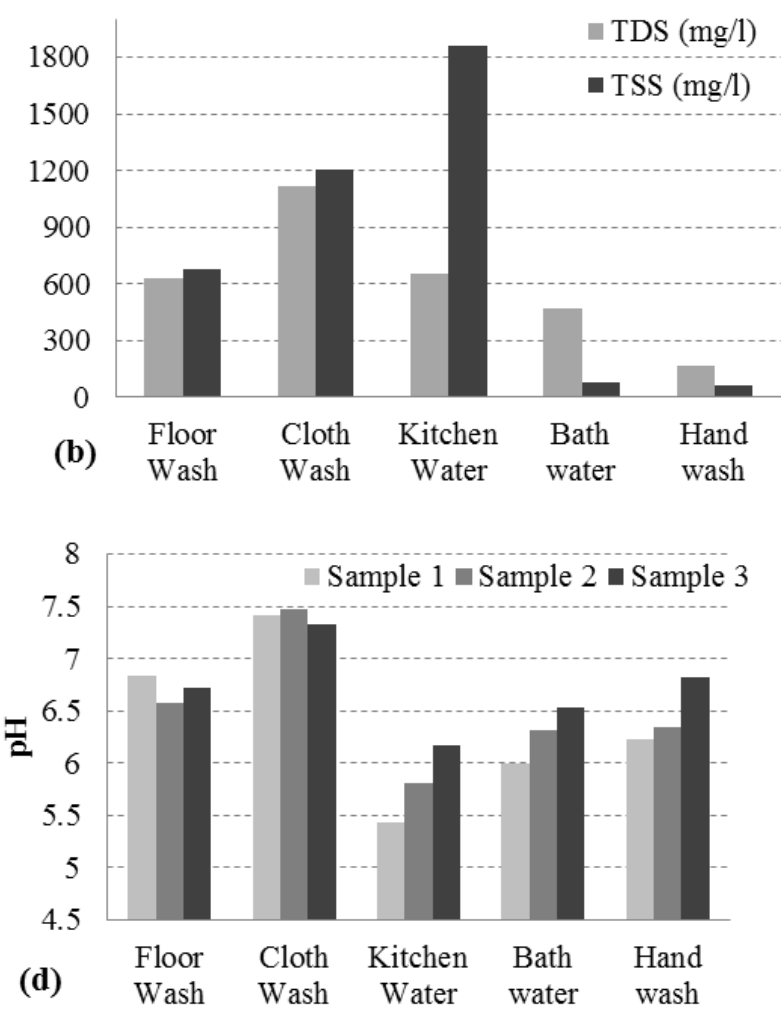

(a) average BOD-COD (b) average TDS-TSS (c) average

greases, and food particles, and its low contribution to the total waste stream for a household, kitchen water is not recommended as a source of greywater. A number of key issues of concern need to be taken into attention when intending the reuse of greywater. The system should be as simple and easy to use and maintain as possible, while reducing risk to human health. If storage is required, the greywater must be treated to eliminate biodegradable contaminants; otherwise the greywater will quickly become septic and may generate toxic odors and create other aesthetic and operational problems. Stresses on water resources for household, commercial, industrial and agricultural purposes are greatly increasing. Given the hasty spread of water pollution and the growing concern about water availability, the links between quantity and quality of water supplies have become more apparent. Ground water depletion has become alarming in Dhaka City for the last few years, and in many areas there is already a widespread scarcity and increased pollution of freshwater resources. The recycling and reuse of greywater are therefore imperative in those and other areas to meet the demand for urban, industrial and agricultural water requirements. Reuse of greywater can be a supplementary source to the existing water sources. Results of this study can lay the foundation for development of greywater reuse and recycling and, thus; reduce the stress on water resources in Dhaka City. 


\section{Recommendations}

Some scopes of the study that can follow the present assessment are quality analysis from the zones of Dhaka City other than the ones present in this study. Quality analysis after treatment may be a significant extension of the work which might later lead to the selection of suitable treatments required for reusing greywater. Survey can be done to find out the possible level of public acceptance of greywater reuse.

\section{Acknowledgements}

Authors are grateful to the lab assistants at the 'Environmental Engineering Laboratory' of Bangladesh University of Engineering and Technology (BUET) for their assistance during the testing of quality parameters. They also express gratitude towards the families that helped conduct the survey for quantification of greywater generation.

\section{References}

Akhter, H., Ahmed, M.S., Rasheed, K.B.S. 2009. Spatial and Temporal Analysis of Groundwater Level Fluctuation in Dhaka City, Bangladesh, Asian Journal of Earth Sciences 2 (2): 49-57,2009 ISSN 1819-1886.

Almeida, M.C., Butler, D., Friedler, E. 1999. Atsource domestic wastewater quality. Urban Water, 1, pp: 49-55.

http://dx.doi.org/10.1016/S1462-0758(99)00008-4

Anderson, M. J. 1996. Current water recycling initiatives in Australia: Scenarios for the 21st century. Water Science and Technology, 33(11), 37-43. http://dx.doi.org/10.1016/0273-1223(96)00404-0

Angelakis, A., Asano, T., Diamadopoulos, E., And Tchobanoglous, G. 1995. Wastewater reclamation and reuse. Selected Proceedings of the International Association for Water Quality 2nd International symposium on wastewater reclamation and reuse, Iraklio, Crete, Greece, 17-20 October, $492 \mathrm{pp}$.

Art Ludwig, The New Create an Oasis with Greywater: Choosing, Building and Using Greywater Systems -Includes Branched Drains, Revised and Expanded $5^{\text {th }}$ Edition,

[http://www.oasisdesign.net/greywater/createanoasis/]

Asano, T., Maeda, M., Takaki, M. 1996. Wastewater reclamation and reuse in Japan: overview and implementation examples. Water Science Technology, 34(11), 319-226, http://dx.doi.org/10.1016/S0273-1223(96)00841-4

Athens, L., And Ferguson, B. K. 1996. "Water issues." In: Sustainable Building Technical Manual, Public technology, Inc., Portland, OR, 52-64.

BC Green Building Code Background Research, Greywater Recycling, October 2007.

Capital Regional District. "Greywater Reuse Study Report." November 1, 2004.

[http://www.crd.bc.ca/reports/water_/2004_/crdgreywaterre usestu/CRDGreywaterReuseStudyFinalReport.pdf]

Carden, K., Armitage, N., Winter, K., Sichone, O. \& Rivett, U. 2007. Understanding the use and disposal of greywater in the non-sewered areas in South Africa. Report to the Water Research Commission WRC Report No 1524/1/07, South Africa.

Cdph, California Department of Public Health. 2001. California Health Laws Related to Recycled Water. The Purple Book. Excerpts from the Health and Safety Code, Water Code, and Titles 22 and 17 from the California Code of Regulations.

Center for the Study of the Built Environment (CSBE). 2003. Greywater Reuse in Other Countries and its Applicability to Jordan. Funded by the Ministry of Planning, Kingdom of Jordan.

[http://www.csbe.org/graywater/report/report_final.pdf]

Christensen, B. 2006. A sourcebook for green and sustainable building. (December 5, 2006).

[http://www.greenbuilder.com/sourcebook/]

Christova-Boal, D., Eden, R. E. \& Mcfarlane, S. 1996. An investigation into greywater reuse for urban residential properties. Desal, 106(1-3), 391-7.

Christova-Boal, D., Lechte, P., \&Shipton, R. 1995. Installation and Evaluation of Domestic Graywater Systems. Executive Summary. Department of Civil and Building Engineering. Victoria University of Technology, Victoria, Australia. Retrieved February 15, 2009.

CIA World Factbook. 2013

https://www.cia.gov/library/publications/the-worldfactbook/fields/2119.html (Online: accessed 05th May 2013).

Clark, J. W., Viessman, Jr. W., \& Hammer, M. J. 1977. Water Supply and Pollution Control. New York: Harper and Row publishers. ISBN 0-7002-2495-5, 857 pp.

CSBE, Center for the Study of the Built Environment. 2003. Graywater Reuse in Other Countries and its Applicability to Jordan. Funded by the Ministry of Planning, Kingdom of Jordan.

[http://www.csbe.org/graywater/report/report_final.pdf]

Dean, R. And Lund, E. 1981. Water ReuseProblems and Solutions. New York: Academic Press, 264pp.

DWASA, Dhaka Water Supply and Sewerage Authority [http://www.dwasa.org.bd/] [Online: accessed 05th March 2013]

EPA. 2004. Guidelines for Water Reuse. U.S. Environmental Protection Agency. Washington DC.

Faruqui, N. And Al-Jayyousi, 0. 2002. Greywater Reuse in Urban Agriculture for Poverty Alleviation: A Case-Study in Jordan. Water International, 27-3.

GLOBAL DM 2005: Livelihoods in a Sustainable Environment, Department of Environmental Affairs, Ministry of Water and Environment, Yemen. [http://wbi.worldbank.org/developmentmarketplace/idea/reu sing-mosque-water-irrigation-yemen]

Greywater Recycling Basics,

[http://www.letsgogreen.com/greywater-recycling.html] [Online: accessed 27th October 2011]

Gulyas, H. 2007. Greywater reuse - Concepts, benefits, risks and treatment technologies. International Conference on Sustainable Sanitation - Food and Water Security for Latin America, Fortaleza, Ceará, Brazil.

Gunther, F. 1999. "Wastewater treatment by greywater separation: Outline for a biologically based greywater purification plant in Sweden." Ecological Engineering, 15, 139-156.

http://dx.doi.org/10.1016/S0925-8574(99)00040-3

Gunther, F. 2000. Wastewater treatment by greywater separation: outline for a biologically based greywater plant in Sweden, Ecological Engineering. 15: 136-14 http://dx.doi.org/10.1016/S0925-8574(99)00040-3

Gunther, F. Wetparks: Not a new way to purify water [http://www.holon.se/folke/projects/vatpark/concept.shtml] [Online: accessed 27th June 2012] 
Gunther, F., 1995."Wastewater treatment by source separation: biologically based greywater purification" (http://www.holon.se/folke/projects/vatpark/Kth/guntha.sht ml\#Outline) (April 30, 2007).

Haddadin, Munther J. (ed). 2006. Water Resources in Jordan: Evolving Policies for Development, the Environment and Conflict Resolution, REF Press, Washington DC, Chapter I.

PMCid:3167077

Hoffmann, H., Platzer, C., Winker, M., Muench, E Von. 2011. Technology review of constructed wetlands Subsurface flow constructed wetlands for greywater and domestic wastewater treatment, Deutsche Gesellschaft für, Internationale Zusammenarbeit (GIZ) GmbH, Sustainable sanitation - ecosan program, Postfach 5180, 65726 Eschborn, Germany.

Islam, N. 1996. Dhaka: From City to Mega City. Dhaka: Urban Studies Program.

Jefferson, B., Palmer, A., Jeffrey, P., Stuetz, R., Judd, S. 2004. Grey water characterisation and its impact on the selection and operation of technologies for urban reuse, Water Science \& Technology Vol 50 No 2 pp 157-164. PMid:15344786

Jeppesen, B. 1996. Domestic greywater re -use: Australia's challenge for the future. Desal, 106(1-3), 311-5.

KADUVINAL, J. 2007. Effects of the implementation of greywater reuse systems on construction cost and project schedule, Texas A \& M University.

Khan, H. And Siddique, Q. 2000. Urban water management problems in developing countries with particular reference to Bangladesh. Water Resources Development 16(1).

Khong, Chung M. 2009. Perception and use of graywater in Berkeley, California. Master's Theses. San Jose State University, Paper 3693.

Kraft, L. 2009. Characterisation of greywater from peri-urban areas in Nakuru, Kenya. Diploma thesis, University of Applied Sciences Weihenstefan, Germany (Fachhochschule Weihenstephan Abteilung Triesdorf).

Maeda, M., Nakada, K., Kawamoto, K., And Ikeda, M. 1996. "Area wide reuse of reclaimed water in Tokyo, Japan." Water Science and Technology, 33(11), 51-57. http://dx.doi.org/10.1016/0273-1223(96)00406-4

Mc-Llwaine S. 2004. Reusing Domestic Greywater as a Method of Water Demand Reduction in Jordan. Paper presented in Water Demand Management Conference at the Dead Sea, 2004.

Morel, A. And Diener, S. 2006. Greywater Management in Low and Middle Income Countries. Review of Different Treatment Systems for Households or Neighborhoods.

Mori, A. 1993. Treatment and Recycling of Sewage Sludge in Yokohama, Proceedings of the 15th Federal Convention of Australian Water and Wastewater Association, 18-23 April, 1993, p 682-688.

Mungai, G. 2008. Impacts of long-term greywater disposal on soil properties and reuse in urban agriculture in an informal settlement - a case study of Waruku, Nairobi. MSc thesis MWI 2008/10, UNESCO-IHE Institute for Water Education, Delft, The Netherlands.

National Aeronautics and Space Administration (NASA). 2007. "The water cycle." [http://neptune.gsfc.gov/education/watercycle.php] (Online: accessed February 23, 2007).
Nolde, E. 2005. Greywater recycling systems in Germany-results, experiences and guidelines. Water Science and Technology, 51(10), 275-284.

Oasis Design. "Greywater Policy Packet." 2005. [http://www.oasisdesign.net/downloads/GWPolicyPacket.pd f]

Pedersen, A., Woelfe-Erskine, C., And Hill-Hart, J. 2007. Gray Water Policy Proposal, University of MontanaEnvironmental Studies

[http://greywateraction.org/content/policyrecommendations-montana]

Platzer, M., Cáceres, V., Fong, N. 2004. The reuse of treated wastewater for agricultural purposes in Nicaragua; Central America. Water Science and Technology, 50(2), 293-300.

PMid:15344804

Raude, J., Mutua, B., Chemelil, M. \& Sleytr, K. 2009. Characterisation of urban and peri-urban greywater of Nakuru municipality, Kenya. 34th WEDC conference in Addis Ababa, Ethiopia.

PMCid:3167643

Ridderstolpe, P. 2004. Introduction to greywater management, Stockholm Environment Institute, Sweden, Report 2004-4.

Roesner, L., Qian, Y., Criswell, M., Stromberger, M., \& Klein, S. 2006. Long Term Effects of Landscape Irrigation Using Household Graywater-Literature Review and Synthesis. The Water Environment Research Foundation and the Soap and Detergent Association. Retrieved February 15, 2009.

Tamanna, M. 2011. Greywater Generation and Quality Measurement at a Specific Site in Dhaka City, Undergraduate thesis, Bangladesh University of Engineering and Technology.

Tchobanoglous, G., Angelakis, A. N. 1996. Technologies for wastewater treatment appropriate for reuse: Potential for applications in Greece. Water Science and Technology, 33(10-11), 17-27.

UNDP (United Nations Development Programme). 1995. Human Development Report 1995: Gender and Human Development Technical Report. UNDP, New York.

UNDP. 2006. Human Development Report 2006: Beyond Scarcity: Power, Poverty, and the Global Water Crisis. Palgrave Macmillan, New York.

UNEP. 1992. World Atlas of Desertification. Edward Arnold, London.

UNWWAP. 2003. United Nations World Water Assessment Programme. The World Water Development Report 1: Water for People, Water for Life. UNESCO: Paris, France.

USEPA (US Environmental Protection Agency). 2004. Guidelines for Water Reuse. Report EPA/625/R04/108, USEPA, Washington, DC, USA.

Vigneswaran, S., Sundaravadivel, M. 2004. Recycle And Reuse of Domestic Wastewater, in Wastewater Recycle, Reuse and Reclamation, [Ed. Saravanamuthu (Vigi) Vigneswaran], in Encyclopedia of Life Support Systems (EOLSS), Developed under the Auspices of the UNESCO, Eolss Publishers, Oxford, UK, [http://www.eolss.net]

Winward, G.P. 2007. Disinfection of greywater, Cranfield University. 
Shaikha Binte Abedin - Lecturer, Department of Civil Engineering, University of Information Technology and Science, Dhaka, Bangladesh.

Main research area: Water Pollution and Control, Air pollution and Control, Hydrology, Hydrometeorology, Remote sensing.

Address: Jamalpur Twin Tower (Tower 2), Baridhara View, GA - 37/1 Pragati Sharani, Baridhara, J-Block, Dhaka 1212, Bangladesh.

Tel.:

E-mail:
$+8801675583062$

shaikha.abedin@gmail.com

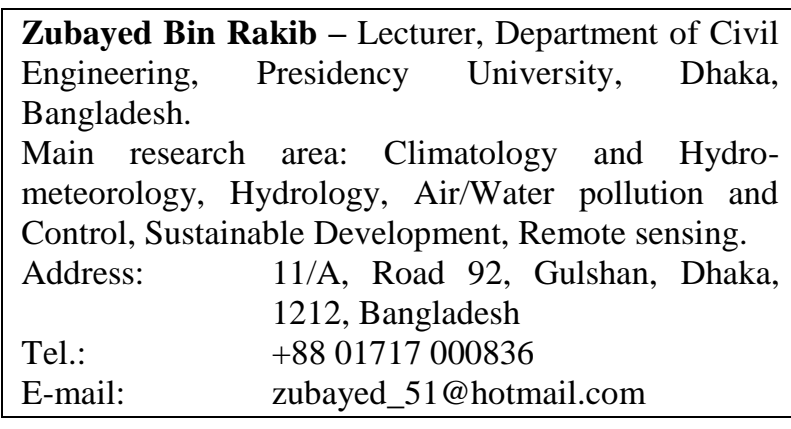

\title{
Paplavų susidarymo ir kokybès analizė Dakos mieste
}

\author{
Shaikha Binte Abedin ${ }^{1}$, Zubayed Bin Rakib ${ }^{2}$ \\ ${ }^{1}$ Statybos inžinerijos katedra, Informaciniu technologiju ir mokslu universitetas, Daka, Bangladešas \\ ${ }^{2}$ Statybos inžinerijos katedra, Prezidentinis universitetas, Daka, Bangladešas
}

(gauta 2013 m. balandžio mèn., priimta spaudai 2013 m. birželio mèn.)

\begin{abstract}
Gamtinis išteklius - vanduo - nèra laisvai prieinamas daugeliui pasaulio žmonių. Daugèjant pasaulyje žmoniu ir didejjant urbanizacijai, auga vandens poreikis. Dẻl didejjančio vandens naudojimo vykdant intensyvią žemdirbystę besivystančiose šalyse ir neefektyvaus vandens naudojimo pažangiose valstybėse labai trūksta tyro vandens visame pasaulyje ir jo trūks ateityje. Šiuo metu pasaulis yra kryžkelèje, kai nedarnus ir nepraktiškas vandens naudojimas negali būti toleruojamas. Būtinas vandens perdirbimas ir antrinis panaudojimas kai kuriuose regionuose, norint tenkinti didejjanti vandens poreiki miesto, pramonès ir žemès ūkio reikmėms. Paplavos, apibūdinamos kaip nuoteku iš pastatu srautas, neitraukiant tualetų nuotekų gali būti potencialus antrinio vandens panaudojimo šaltinis miestuose, nes jame yra mažai arba visai nèra patogenų ir 90 proc. mažiau azoto nei bendrose nuotekose. Šiame straipsnyje aprašomas paplavų susidarymas ir jų kokybė Dakos mieste. Kasmet Dakos mieste gruntinių vandenu kiekis sumažėja 2/3 metro. Todèl vandens antrinis panaudojimas tampa labai aktualus, siekiant kompensuoti gruntinio vandens trūkumą. Siekiant ịvertinti paplavų susidarymą Dakos mieste, buvo analizuoti penki namų ūkiai. Nustatyta, kad apie 67 proc. vandens gali būti antrą kartą naudotinas, o 17 proc. vandens buvo užteršta tualeto nuotekomis. Atliekant kokybinę analizę nustatyta, kad virtuvės paplavų vanduo buvo iš dalies užterštas, todèl antriniam naudojimui jis nèra tinkamas. Paplavų vanduo turi būti valomas prieš naudojant ji antrą kartą, nes jo užterštumas viršija bet kokius priimtinus geriamo ir drèkinimui skirto vandens standartus.
\end{abstract}

